\title{
PENGARUH PRA-PERLAKUAN ADSORPSI KARBON AKTIF TERHADAP FOULING MEMBRAN ULTRAFILTRASI POLISULFON (UF-PSf) PADA PENYISIHAN BAHAN ORGANIK ALAMI (BOA) AIR GAMBUT \\ EFFECT OF ACTIVATED CARBON PRETREATMENT TO FOULING OF POLYSULFONE ULTRAFILTRATION (UF-PSf) MEMBRANE FOR REMOVAL OF NATURAL ORGANIC MATTER (NOM) IN PEAT WATER
}

\author{
Aulia Rahma ${ }^{1}$ Mahmud dan Chairul Abdi ${ }^{2}$ \\ ${ }^{1}$ Mahasiswi Program Studi Teknik Lingkungan, Fakultas Teknik,ULM \\ ${ }^{2}$ Dosen Program Studi Teknik Lingkungan, Fakultas Teknik, ULM JL. \\ A. Yani Km 36, Banjarbaru, Kalimantan Selatan, 70714, Indonesia \\ E-mail: rahmaaulia95@gmail.com
}

\begin{abstract}
ABSTRAK
Fouling merupakan salah satu kendala yang membatasi kinerja membran ultrafiltrasi (UF). Keberadaan Bahan Organik Alami (BOA) menjadi penyebab utama terjadinya fouling membran pada air gambut. Pra-perlakuan adsorpsi mampu menjadi solusi untuk mengurangi fouling dan meningkatkan performa membran UF polisulfon (UF-PSf). Penelitian ini bertujuan untuk menyelidiki pengaruh pra-perlakuan adsoprsi terhadap perubahan nilai fluks pada membran UF- PSf, dan menganalisis model pembentukan fouling yang paling tepat untuk menggambarkan proses hibrid adsorpsi dan UF-PSf. Proses hibrid adsorpsi dan UF-PSf dilakukan pada kondisi optimum dengan pH 4 dan dosis optimum Powdered Activated Carbon (PAC) 1040 mg/L pada tekanan 1-3 bar. Tekanan operasi terbaik terjadi pada tekanan 3 bar dengan nilai fluks permeat sebesar 85,064 $\mathrm{L} / \mathrm{m}^{2}$.jam dan rejeksi BOA sebesar 85,24\% (UV 254$)$ dan 85,07\% (KMnO4). Modified Fouling Index (MFI) merupakan pemodelan yang tepat untuk menggambarkan pembentukan fouling pada proses hibrid adsorpsi dan UF-PSf pada penyisihan BOA air gambut. Tekanan 1 bar memiliki potensi fouling yang tinggi dengan nilai $R^{2}$ sebesar 0,998.
\end{abstract}

Kata kunci: air gambut, bahan organik alami, fouling, MFI, ultrafiltrasi

\begin{abstract}
Fouling is one of the constraint that limit the performance of ultrafiltration (UF) membranes. The presence of natural organic matter (NOM) is one of the main causes of fouling membrane in peat water. Adsorption pretreatment is applicable to this problem in order to reduce of fouling membrane and enhance UF-PSf membrane performance. The objectives of this research are to investigate the effect of adsorption pretreatment to flux on UF-PSf membrane, and to analyze the forming of fouling model for hybrid adsorption and UF-PSf process. Hybrid adsorption and UF-PSf process conducted under optimum conditions with $\mathrm{pH} 4$ and Powdered Activated Carbon (PAC) dose of $1040 \mathrm{mg} / \mathrm{L}$ at pressure 1-3 bar. The best operating pressure occurs at 3 bar with permeate flux is $85,064 \mathrm{~L} / \mathrm{m}^{2}$.jam and rejection of NOM are 85,24 (UV 254$)$ and 85,07\% (KMnO 4$)$. Modified Fouling Index (MFI) is an appropriate model to illustrated the formation of fouling on hybrid adsorption and UF-PSf process on BOA removal in peat water. Pressure 1 bar has a high fouling potential with $R^{2} 0,998$.
\end{abstract}

Keywords: fouling, MFI, NOM, peat water, ultrafiltration 


\section{PENDAHULUAN}

Secara kuantitatif air gambut berpotensi dimanfaatkan sebagai sumber air baku di Kalimantan. Air gambut memiliki karakteristik yang khas, yakni memiliki $\mathrm{pH}$ rendah (pH 3,7-4,3), berwarna coklat tua dan mengandung senyawa organik yang tinggi $\left(38-280 \mathrm{mg} / \mathrm{L} \mathrm{KMnO}_{4}\right)$ yang dipengaruhi oleh kondisi tanah gambut dibawahnya (Pratiwi dkk., 2016). Bahan organik alami (BOA) dalam air gambut merupakan salah satu parameter kunci kualitas air yang mempengaruhi proses pengolahan air minum (Aziza, 2013). Keberadaan BOA pada air gambut dapat menyebabkan warna, bau, kromatisasi, dan pertumbuhan kembali biologi pada jaringan distribusi air yang menyebabkan terbentuknya produk samping dari desinfeksi berupa senyawa karsinogen (Tang dkk., 2014, Zularisam dkk., 2009).

Ultrafiltrasi (UF) merupakan metode yang dapat digunakan untuk menyisihkan BOA pada air gambut.. Beberapa penelitian melaporkan membran UF mampu menyisihkan kandungan BOA pada air gambut (Herwati dkk., 2015, Notodarmojo dan Deniva, 2004, Syarfi, 2007, Wardani, 2013). Meskipun membran berpotensi dalam pengolahan air, akan tetapi dalam penerapannya ditemukan satu masalah utama yakni terjadinya fouling (Zularisam dkk., 2006). Fouling dapat menurunkan fluks membran (Zularisam dkk., 2007), menurunkan kinerja membran, meningkatkan biaya operasi, dan seringnya pencucian membran (Mahmud dan Noor, 2005).

BOA merupakan faktor utama penyebab fouling membran UF pada air permukaan (Arhin dkk., 2016, Campinas dan Rosa, 2010, Gao dkk., 2011). Menurut Malczewska dan Benjamin (2016) BOA dengan berat molekul kecil berpengaruh besar terhadap terjadinya fouling. Kim dkk. (2008) menyebutkan karbon aktif dapat menyisihkan BOA dengan berat molekul kecil (lebih kecil dari diameter pori membran). Pra-perlakuan adsorpsi berpengaruh terhadap penyisihan organik dalam membran karena sifat karbon aktif yang mampu mengikat molekul organik sehingga dapat memperkecil kemungkinan terjadinya fouling (Widjaja dkk., 2009). Karbon aktif merupakan adsorben yang sering digunakan pada proses hibrid adsorpsi-UF karena kemampuannya yang bagus dalam menyisihkan kontaminan serta ketersediaannya mudah didapat (Gao dkk., 2011). Beberapa penelitian melaporkan pra-perlakuan adsorpsi pada UF dapat meningkatkan fluks, kinerja filtrasi lebih lama dan mengurangi frekuensi pencucian membran secara kimia (Konieczny dan Klomfas, 2002, Lee dkk., 2007).

Selulosa asetat (CA) merupakan bahan pertama pembuat membran asimetrik dengan sifat ketahanan yang terbatas terhadap bahan kimia, sehingga diperlukan bahan polimer lain yang lebih baik (Sivakumar dkk., 2006). Polimer lain yang dapat digunakan sebagai bahan pembuat membran adalah polisulfon (PSf). PSf memiliki karakteristik mekanik yang baik, struktur yang kuat dan stabil pada pH 1-13, namun bersifat hidrofobik yang berpotensi meningkatkan fouling membran (Wardani, 2013). Modifikasi membran dengan aditif polietilen glikol (PEG) dapat mengubah sifat membran PSf menjadi hidrofilik sehingga fouling dapat direduksi (Yunos dkk., 2014). Sebelumnya Aziza (2013) telah melakukan penelitian mengenai pengaruh jenis adsorben terhadap fouling pada proses hibrid adsorpsi dan UF berbahan selulosa asetat untuk menyisihkan BOA dalam air gambut. Namun demikian, belum ada penelitian mengenai pengaruh pra-perlakuan adsorpsi karbon aktif terhadap fouling membran berbahan polisulfon pada penyisihan BOA air gambut. Penelitian ini dilakukan untuk menyelidiki pengaruh adsorpsi karbon aktif terhadap perubahan nilai fluks pada membran UFPSf, dan menganalisis model pembentukan fouling yang paling tepat untuk menggambarkan proses hibrid adsorpsi dan UF-PSf. 


\section{METODE PENELITIAN}

\subsection{Sampel Air Gambut}

Sampel air yang digunakan pada penelitian ini diambil dari Jl. A.Yani Km 17 Kecamatan Gambut, Kalimantan Selatan. Sampel disimpan dan dihomogenkan dalam satu wadah yang telah dilapisi penutup gelap. Karakterisasi air gambut dilakukan dengan mengukur parameter DOC, $\mathrm{UV}_{254}, \mathrm{KMnO}_{4}$ untuk mengetahui kandungan BOAnya dan $\mathrm{pH}$. Pemeriksaan dilakukan seminggu sekali selama satu bulan untuk mengetahui perubahan kandungan BOA terhadap waktu. Karbon aktif yang digunakan pada proses pra-perlakuan adsorpsi adalah powdered activated carbon (PAC) Merck.

\subsection{Proses Hibrid adsorpsi dan UF-PSf}

Membran yang digunakan pada penelitian ini adalah membran polisulfon (PSf) yang telah dimodifikasi dengan aditif poli etilen gliko (PEG) 600. Komposisi dan metode pembuatan membran PSf mengacu pada penelitian Tutriyanti (2017) menggunakan teknik inversi fasa dengan impregnasi $\mathrm{KCl} 0,5 \%$. Selanjutnya melakukan percobaan pra-perlakuan adsorpsi dengan $\mathrm{pH}$ optimum 4 dan variasi dosis PAC 80-1120 mg/L dengan kecepatan pengadukan $180 \mathrm{rpm}$ selama 2 jam mengacu pada penelitian Aziza (2013). Kemudian air hasil olahan disaring dengan vacum filter untuk dianalisis kandungan BOAnya. Dari analsis tersebut akan didapatkan dosis optimum proses pra-perlakuan adsorpsi yang kemudian dilanjutkan ke tahap UF.

Tahapan proses hibrid adsorpsi dan UF-PSf yaitu meletakkan kertas saring sebagai support di bawah dan di atas memran dalam sel ultrafiltrasi. Skema alat ultrafiltrasi dapat dilihat pada Gambar 1. Sistem aliran yang digunakan adalah dead-end dengan mengukur volume permeat setiap 5 menit dengan waktu operasi 60 menit. Selanjutnya dilakukan analisis permeat untuk mengetahui rejeksi BOA pada proses hibrid adsorpsi dan UF-PSf. Percobaan tersebut juga dilakukan pada larutan blanko (akuades+PAC) dengan perlakuan yang sama untuk mengetahui pengaruh adsorben pada proses pembentukan fouling membran.

\subsection{Metode Analisis}

Parameter yang dianalisis adalah DOC, absorbansi $\mathrm{UV}_{254}$, zat organik $\left(\mathrm{KMnO}_{4}\right)$ dan $\mathrm{pH}$. DOC ditentukan menggunakan TOC analyzer (Shimadzu TOC-L). Absorbansi UV 254 diukur menggunakan alat UV-1600 Spectrophotometer, sedangkan zat organik dianalisis dengan metode titrasi permanganometri. Pengukuran $\mathrm{pH}$ dilakukan menggunakan $\mathrm{pH}$ meter (Hanna). Karakterisasi membran dilakukan melalui perhitungan permeabilitas membran dengan mengukur fluks akuades pada variasi tekanan operasi 1-3 bar. Analisis morfologi membran menggunakan Scanning electron microscope (SEM) pada tampak permukaan dan penampang melintang dengan perbesaran 1000x dan 2500x. Data digital foto SEM dianalisis lanjutan dengan softwere Image-J untuk mengetahui ukuran pori membran mengacu pada Kurniawan dkk. (2011). 


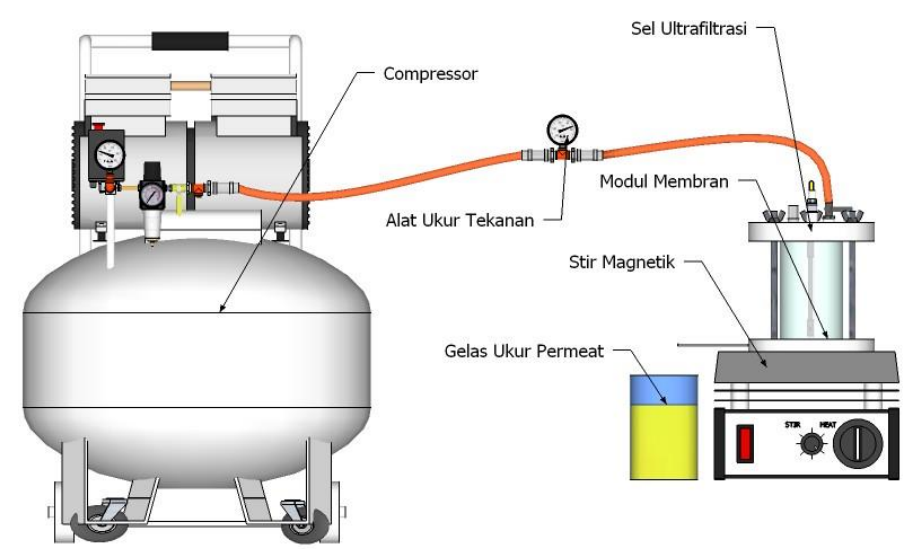

Gambar 1. Skema alat operasi UF sistem aliran dead-end

\section{HASIL DAN PEMBAHASAN}

\subsection{Karakterisasi Sampel Air Gambut}

Hasil analisis karakterisasi air gambut yang diambil dari Jl. A.Yani Km 17 kecamatan Gambut, Kalimantan Selatan disajikan pada Tabel 1. Kandungan DOC dan zat organik yang digunakan pada penelitian ini relatif tinggi yaitu $36,4 \mathrm{mg} / \mathrm{L}$ (DOC) dan $120,1 \mathrm{mg} / \mathrm{L} \mathrm{KMnO}_{4}$ (zat organik), hasil ini sesuai dengan air gambut yang dilaporkan Aisyahwalsiah (2013) dan Saputri (2008).

Tabel 1 menunjukkan nilai $\mathrm{UV}_{254}$ yang digunakan pada penelitian ini relatif kecil dibandingkan dengan $U^{254}$ yang dilaporkan Herwati dkk. (2015), Saputera (2014) berkisar antara 1,646-2,503 $1 / \mathrm{cm}$. Hal tersebut terjadi karena lokasi pengambilan sampel yang berbeda dengan penelitianpenelitian sebelumnya. Parameter SUVA mengindikasikan karakter aromatik pada air permukaan. nilai SUVA pada Tabel 1 sebesar 2,723 L/mg.m berarti BOA merupakan campuran hidrofobik dan hidrofilik dengan berat molekul campuran sesuai teori Edzwald dan Tobiason (1999).

\subsection{Karakterisasi Membran Polisulfon}

\subsubsection{Permeabilitas Membran Polisulfon}

Hasil karakterisasi membran secara fungsional melalui perhitungan fluks akuades untuk melihat permeabilitas membran disajikan pada Gambar 2. Nilai fluks akuades paling tinggi terjadi pada tekanan 3 bar sebesar $179,3 \mathrm{~L} / \mathrm{m}^{2}$.jam sedangkan nilai fluks terendah terjadi pada tekanan 1 bar yaitu $35,5 \mathrm{~L} / \mathrm{m}^{2}$.jam. Kecenderungan yang terjadi adalah semakin besar tekanan operasi, maka nilai fluks yang dihasilkan juga semakin meningkat, begitu pula sebaliknya. Hal tersebut sesuai dengan teori gaya dorong (driving force) dari operasi membran.

Tabel 1. Hasil Karakterisasi Air Gambut

\begin{tabular}{clcccccc}
\hline \hline No & Parameter & Satuan & \multicolumn{2}{c}{ Minggu ke- } & \multirow{2}{*}{ Rata rata } \\
& & & I & II & III & IV & \\
\hline 1 & $\mathrm{UV}_{254}$ & $1 / \mathrm{cm}$ & 0,977 & 1,036 & 0,977 & 0,955 & 0,991 \\
2 & DOC & mg/L & 36,4 & - & - & - & 36,4 \\
3 & pH & - & 6,3 & 6,3 & 6,3 & 6,3 & 6,3 \\
4 & SUVA & L/mg.m & 2,684 & 2,846 & 2,739 & 2,624 & 2,723 \\
5 & Zat organik & mg/L & 120,1 & 126,4 & 120,1 & 113,8 & 120,1 \\
& $\left(\mathrm{KMnO}_{4}\right)$ & & & & & & \\
\hline
\end{tabular}




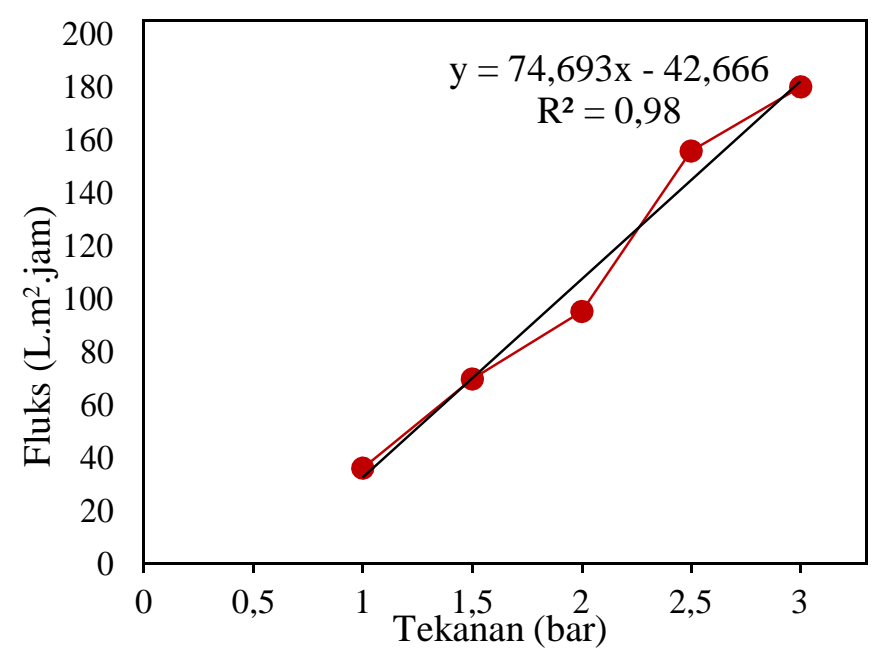

Gambar 2. Grafik hubungan antara fluks akuades terhadap tekanan

Konstanta permeabilitas membran UF menurut Mulder (1996) adalah $50 \mathrm{~L} / \mathrm{m}^{2}$.jam.atm - 500 $\mathrm{L} / \mathrm{m}^{2}$.jam.atm, dan jika merujuk kepada Wenten (1999) nilai permeabilitas UF berkisar 0,5 $\mathrm{m}^{3} / \mathrm{m}^{2}$.hari.bar $-5 \mathrm{~m}^{3} / \mathrm{m}^{2}$.hari.bar $\left(20 \mathrm{~L} / \mathrm{m}^{2}\right.$.jam.bar $-200 \mathrm{~L} / \mathrm{m}^{2}$.jam.bar). Pada Gambar 2 ditunjukkan nilai permeabilitas membran PSf sebesar 74,693 L/m².jam.bar. Sesuai dengan literatur, maka membran PSf yang telah dibuat dapat dikategorikan sebagai membran UF.

\subsubsection{Analisis Morfologi Membran Polisulfon}

Hasil analisa morfologi membran tampak permukaan dan penampang melintang seperti yang ditunjukkan pada Gambar 3 (a dan b) memiliki susunan pori yang rapat dan tidak terdapat makrovoid (rongga besar). Membran PSf yang telah dibuat memiliki struktur pori asimetrik terlihat pada bagian atas membran terdapat lapisan tipis atau skin layer dan bagian bawahnya memiliki pori yang lebih besar yang disebut spinger (Gambar $\mathbf{3}$ b).

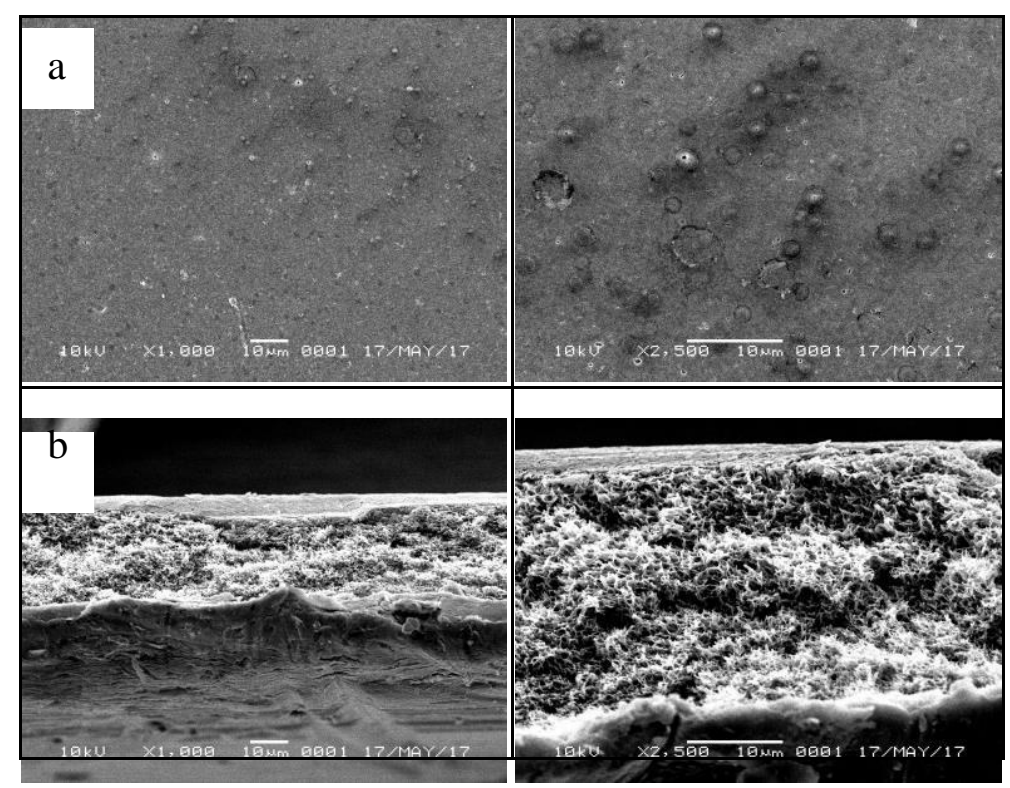

Gambar 3. Foto SEM membran PSf sebelum digunakan perbesaran 1000x dan 2500x (a) tampak permukaan dan (b) penampang melintang 


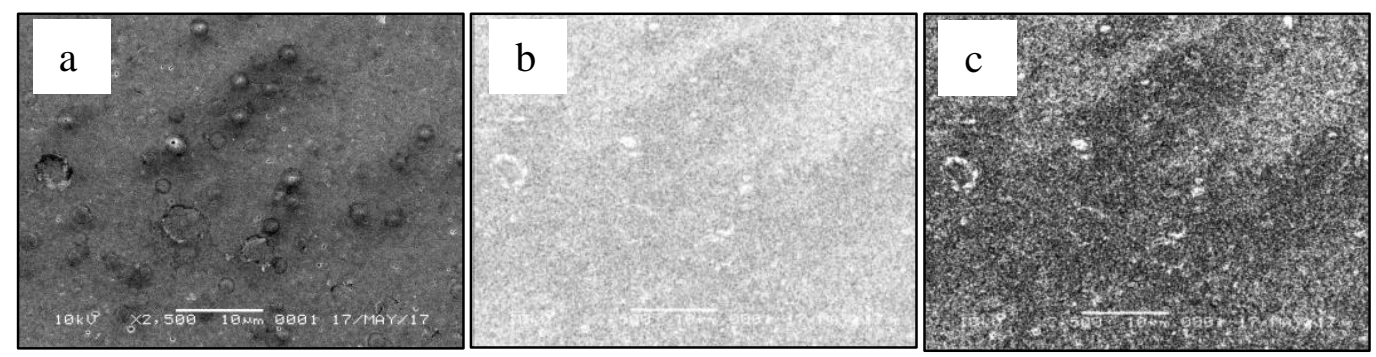

Gambar 4. Hasil pengolahan gambar SEM perbesaran 2500x dengan Image-J (a) sebelum diolah (b) setelah Threshold dan (c) gambar Outline

Membran PSf yang digunakan pada penelitian ini memiliki ukuran pori kurang dari $10 \mu \mathrm{m}$ (Gambar 3 a). Namun dari foto tersebut tidak dapat ditentukan secara pasti berapa ukuran porinya. Penentuan distribusi ukuran pori dilakukan dengan software Image-J mengikuti penelitian Kurniawan dkk. (2011) menggunakan data digital foto SEM. Hasil pengolahan gambar SEM dengan Image-J dapat dilihat pada Gambar 4.

Hasil Image-J pada Gambar 4 didapatkan luas rata-rata pori membran 0,0047 $\mu \mathrm{m}^{2}$ dan diameter ratarata pori membran PSf sebesar $0,0773 \mu \mathrm{m}$. Ukuran pori membran UF berkisar antara $1-100 \mathrm{~nm}(0,001-$ $0,1 \mu \mathrm{m})$ merujuk kepada Mulder (1996). Berdasarkan literatur tersebut maka membran PSf yang digunakan pada penelitian ini dapat dikategorikan sebagai membran UF.

\subsection{Proses Hibrid Adsorpsi dan UF-PSf}

\subsubsection{Penentuan Dosis Optimum Adsorpsi}

Hasil penyisihan zat organik $\left(\mathrm{KMnO}_{4}\right)$ dan $\mathrm{UV}_{254}$ pada penentuan dosis optimum proses adsorpsi ditunjukkan pada Gambar 5, dapat dilihat penambahan dosis adsorben berpengaruh terhadap peningkatan penyerapan BOA. Kecenderungan yang terjadi adalah semakin besar penambahan adsorben, maka efisiensi penyisihan BOA juga semakin meningkat.

Pada Gambar 5 disajikan data hubungan antara penyisihan $\mathrm{UV}_{254}$ dan $\mathrm{KMnO}_{4}$ terhadap variasi dosis karbon aktif. Pada dosis 80-320 mg/L (dosis relatif rendah) persentase penyisihan $\mathrm{KMnO}_{4}$ lebih besar daripada persentase penyisihan $\mathrm{UV}_{254}$. Sedangkan pada dosis relatif tinggi (400-1120 mg/L) persentase penyisihan zat organik $\left(\mathrm{KMnO}_{4}\right) \mathrm{UV}_{254}$ relatif sama. Fenomena ini seperti yang dijelaskan oleh Nilson dan DiGiano (1996) bahwa karbon aktif cenderung mengadsorpsi material zat organik dengan berat molekul menengah, sehingga menyisakan sedikit ruang untuk menyerap materi zat organik dengan berat molekul tinggi dan sangat rendah. Setelah zat organik dengan berat molekul menengah diserap, maka penambahan dosis tidak lagi mengalami peningkatan penyisihan zat organik yang signifikan. 


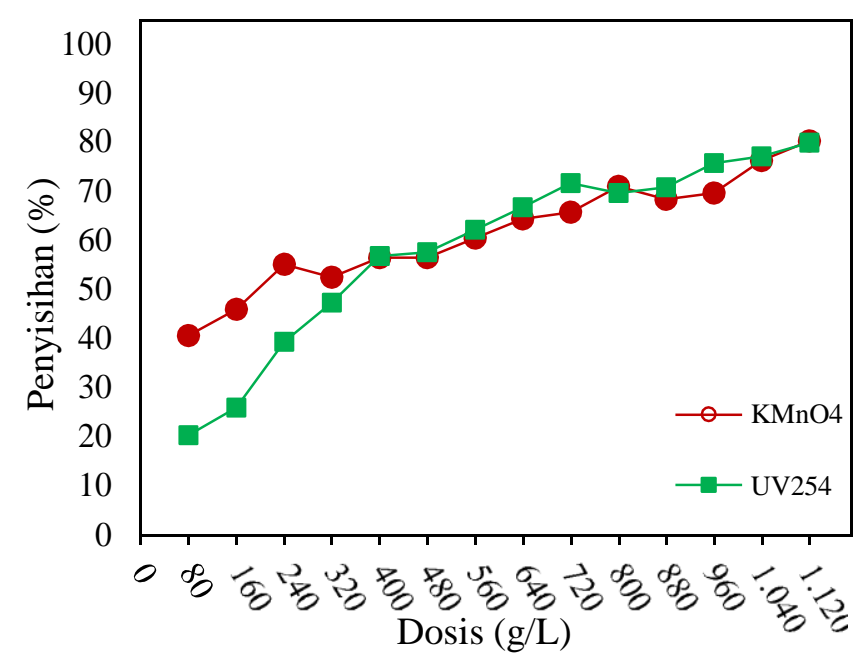

Gambar 5 Grafik hubungan antara persentase penyisihan BOA terhadap dosis

Pada Gambar 5 persentase penyisihan $\mathrm{UV}_{254}$ dan $\mathrm{KMnO}_{4}$ paling tinggi terjadi pada dosis terbesar yaitu $1120 \mathrm{mg} / \mathrm{L}$ sebesar $80 \%\left(\mathrm{UV}_{254}\right)$ dan $80,35 \%\left(\mathrm{KMnO}_{4}\right)$, sedangkan persentase penyisihan paling rendah terjadi pada dosis terendah $80 \mathrm{mg} / \mathrm{L}$ sebesar 20,42\% $\left(\mathrm{UV}_{254}\right)$, dan 40,76 $\left(\mathrm{KMnO}_{4}\right)$. Pola yang terjadi adalah semakin besar penambahan karbon aktif, maka persentase penyisihan BOA juga semakin meningkat. Kondisi optimum proses adsorpsi terjadi pada $\mathrm{pH} 4$ dan dosis optimum 1040 $\mathrm{mg} / \mathrm{L}$ dilihat dari persentase penyisihan $\mathrm{UV}_{254}$ sebesar 77,23\% dan penyisihan $\mathrm{KMnO}_{4} 76,39 \%$ yang memiliki selisih relatif kecil terhadap dosis $1120 \mathrm{mg} / \mathrm{L}$.

\subsubsection{Pengaruh Pra-perlakuan Adsorpsi Terhadap Perubahan Fluks Permeat}

Pra-perlakuan adsorpsi pada memrban UF mampu meningkatkan nilai fluks permeat dibandingkan tanpa pra-perlakuan seperti yang dilaporkan Konieczny dan Klomfas (2002), Lee dkk. (2007), Riduan (2005). Pra-perlakuan adsorpsi mampu meningkatkan flluks air gambut sebesar $43 \%$ seperti yang dilaporkan Riduan (2005). Pra-perlakuan adsorpsi digunakan untuk menyisihkan BOA pada air umpan, sehingga cake/layer yang terbentuk pada permukaan membran dapat direduksi. Hal ini dibuktikan dengan tingkat penyisihan BOA yang tinggi pada proses adsorpsi, sehingga BOA pada umpan dapat direduksi (Gambar 5).

Semakin lama waktu operasi membran, maka fluks permeat yang dihasilkan semakin rendah (Gambar 6). Pada 5 menit pertama nilai fluks tekanan 1 bar sebesar $16,92 \mathrm{~L} / \mathrm{m}^{2}$.jam dan fluks semakin menurun hingga menit ke-60 sebesar 5,31 L/m².jam. Hal tersebut juga terjadi pada tekanan 1,5 bar, 2 bar, 2,5 bar, dan 3 bar. Kecenderungan yang terjadi adalah nilai fluks menurun seiring dengan lama waktu operasi. Hal ini dapat disebabkan karena adanya perbedaan bentuk dan ukuran molekul serta tingkat kekasaran membran sebagai faktor yang berpengaruh terhadap penurunan fluks (Herwati dkk., 2015). 


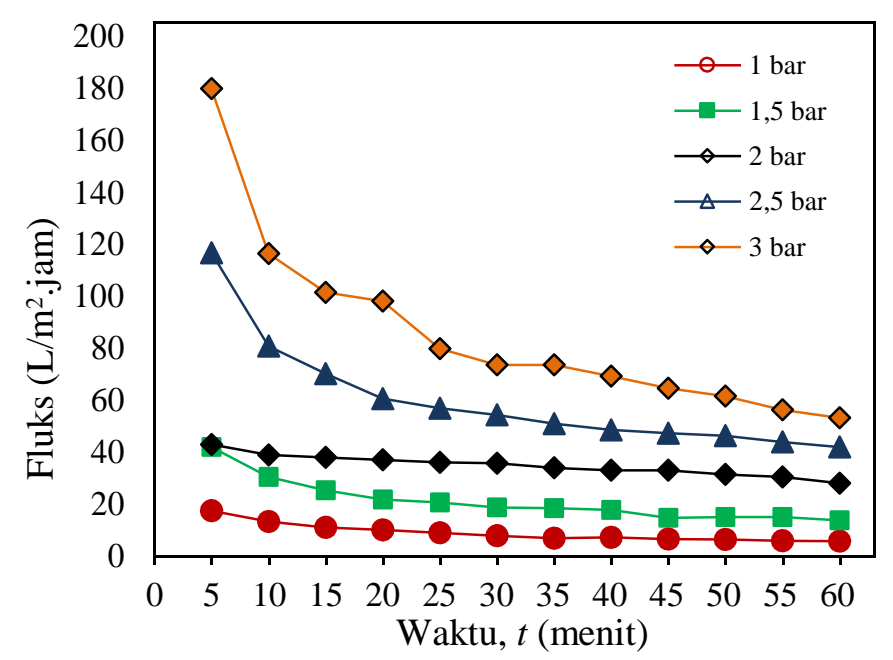

Gambar 6. Grafik hubungan antara fluks permeat terhadap waktu

Dari Gambar 6 dapat dilihat tekanan berpengaruh relatif terhadap fluks. Laju fluks akan mengalami penurunan pada masing-masing tekanan seiring dengan lama waktu operasi. Pada waktu operasi kisaran 0 hingga 15 menit penurunan fluks lebih tajam pada tekanan 2,5 bar dan 3 bar. Pada operasi diatas 15 menit, penurunan fluks relatif landai atau kecil. Sedangkan pada tekanan 1 bar, 1,5 bar, dan 2 bar penurunan fluks relatif landai sepanjang waktu operasi.

Penurunan nilai fluks ( $\mathbf{J}$ ) setiap menitnya mengindikasikan bahwa telah terbentuk fouling membran. Hal ini dibuktikan dari nilai fluks permeat lebih kecil dibandingkan dengan nilai fluks akuades dan fluks blanko (akuades+PAC) yang cenderung lebih tinggi (Gambar 7). Berdasarkan Gambar 7 diketahui nilai fluks blanko memiliki selisih persentase relatif kecil dibandingkan dengan fluks akuades. Hal tersebut menunjukkan bahwa PAC berpengaruh relatif kecil terhadap penurunan fluks seperti yang dilaporkan Mozia dkk. (2005). Sehingga fouling yang terjadi disebabkan oleh keberadaan BOA yang memampat di permukaan membran saat melewatkan umpan air gambut. Fluks dan fouling saling berbanding terbalik. Kecenderungan yang terjadi adalah jika nilai fluks menurun, maka dipastikan fouling meningkat, begitu pula sebaliknya.

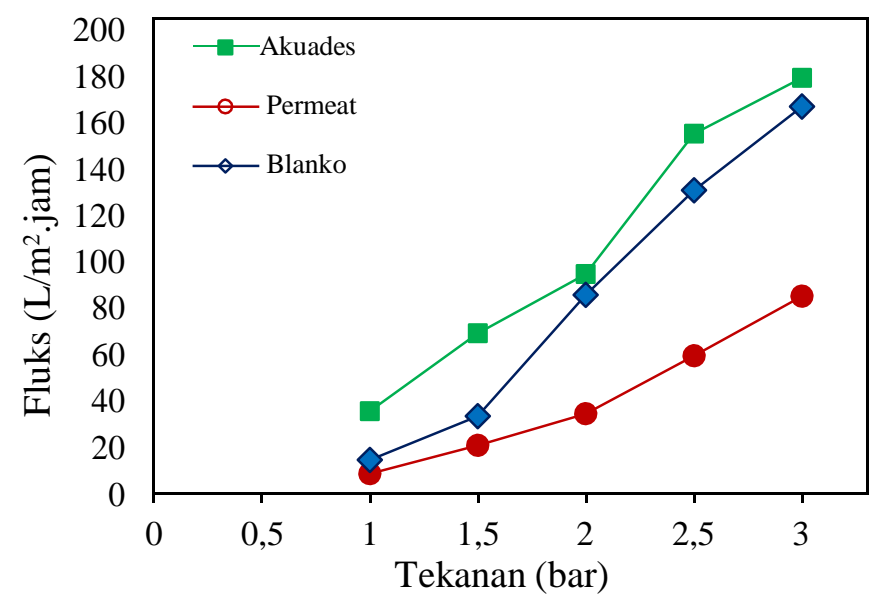

Gambar 7. Grafik hubungan antara fluks akuades, fluks permeat, dan fluks blanko terhadap tekanan 
Pada Gambar 8 menunjukkan pola hubungan antara $\mathrm{J}_{t} / \mathrm{J}_{0}$ terhadap waktu. Semakin kecil $\mathrm{J}_{\mathrm{t}} / \mathrm{J}_{0}$, maka fouling membran yang terjadi semakin besar. Pada Gambar 8 terlihat bahwa nilai $\mathrm{J}_{\mathrm{t}} / \mathrm{J}_{0}$ pada tekanan 2 bar cenderung lebih landai dibandingkan dengan tekanan 1 bar dan 1,5 bar. Nilai $\mathrm{J}_{\mathrm{t}} / \mathrm{J}_{0}$ pada tekanan 3 bar paling tinggi dibandingkan pada tekanan 1 bar, 1,5 bar, 2 bar, dan 2,5 bar.

Berdasarkan Gambar 9 terlihat fluks permeat berbanding terbalik terhadap rejeksi BOA. Pada tekanan 1 bar, fluks permeat yang dihasilkan paling sedikit dibandingkan dengan fluks pada tekanan 1,5 bar, 2 bar, 2,5 bar, dan 3 bar. Kecilnya fluks permeat yang dihasilkan pada tekanan 1 bar cenderung berbanding terbalik dengan rejeksi BOA yang justru paling besar pada tekanan 1 bar. Berbeda dengan tekanan 3 bar, dimana rejeksi BOA paling kecil, namun fluks permeat paling tinggi dibandingkan dengan tekanan 1 bar, 1,5 bar, 2 bar, dan 2,5 bar.

Berdasarkan Gambar 9 dapat dilihat rejeksi penyisihan BOA paling tinggi terjadi pada tekanan 1 bar sebesar 96,49\% $\left(\mathrm{UV}_{254}\right)$ dan $98,61 \%\left(\mathrm{KMnO}_{4}\right)$ dengan nilai fluks terendah $8,46 \mathrm{~L} / \mathrm{m}^{2}$.jam. Sedangkan rejeksi penyisihan BOA terendah terjadi pada tekanan 3 bar sebesar 85,24\% (UV 254$)$ dan 85,07\% $\left(\mathrm{KMnO}_{4}\right)$ dengan nilai fluks paling tinggi sebesar $85,07 \mathrm{~L} / \mathrm{m}^{2}$.jam. Berdasarkan literatur kecenderungan yang terjadi adalah semakin besar tekanan operasi yang diberikan, maka rejeksi akan semakin menurun, hasil ini sesuai dengan penelitian yang dilaporkan Herwati dkk. (2015). Dapat disimpulkan tekanan operasi terbaik pada proses hibrid adsorpsi dan UF-PSf terjadi pada tekanan 3 bar dilihat dari perbandingan fluks permeat dan rejeksi BOA terhadap tekanan pada membran UFPSf pada Gambar 9.

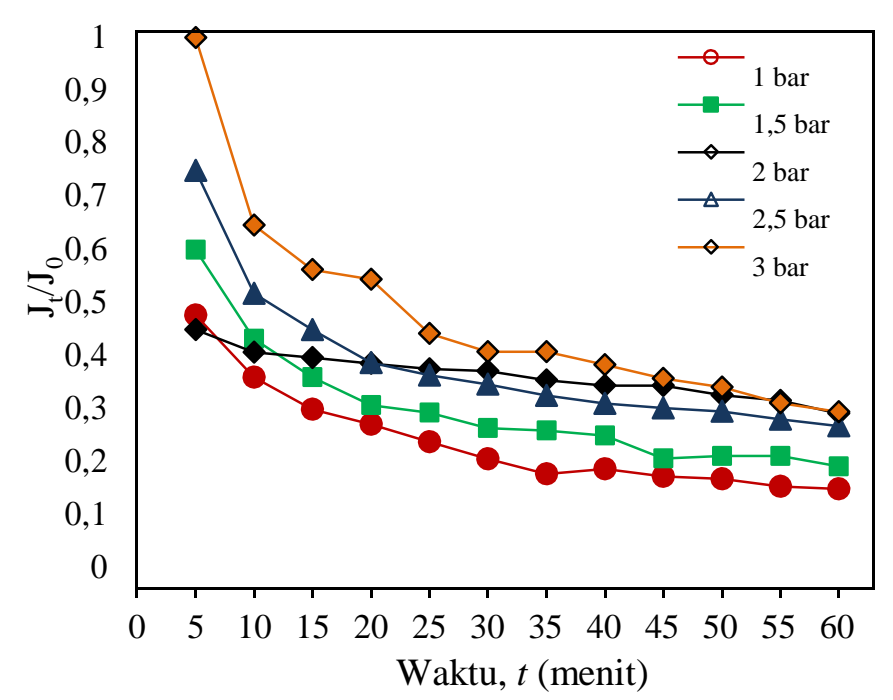

Gambar 8. Grafik hubungan antara $\mathrm{J}_{\mathrm{t}} / \mathrm{J}_{0}$ terhadap waktu 


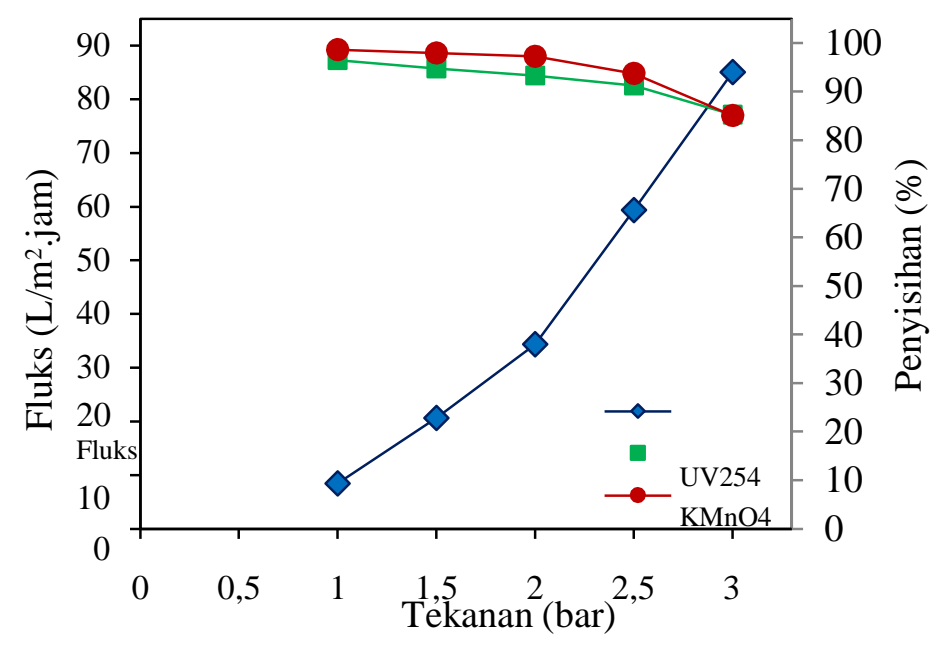

Gambar 9. Grafik hubungan antara fluks permeat dan rejeksi BOA terhadap tekanan

Pada proses hibrid adsorpsi dan UF-PSf, kecenderungan yang terjadi adalah rejeksi $\mathrm{KMnO}_{4}$ lebih tinggi daripada rejeksi $\mathrm{UV}_{254}$ (Gambar 10). Karakteristik air gambut hasil pra-perlakuan adsorpsi memiliki kandungan zat organik $\left(\mathrm{KMnO}^{4}\right)$ dengan berat molekul besar yang lebih tinggi daripada $\mathrm{UV}_{254}$. Parameter $\mathrm{UV}_{254}$ yang tersisa pada permeat merupakan BOA dengan berat molekul kecil yang tidak terserap oleh karbon aktif. Sehingga penyisihan $\mathrm{KMnO}_{4}$ dengan berat molekul besar lebih optimal ditahan oleh membran PSf, sedangkan $U^{254}$ dengan berat molekul kecil dari membran dapat lolos yang mengakibatkan rendahnya penyisihan $\mathrm{UV}_{254}$. Hasil penelitian ini sesuai dengan penelitian yang dilaporkan Notodarmojo dan Deniva (2004) pada penyisihan zat organik, yang menyatakan bahwa ukuran pori dan berat molekul umpan berpengaruh terhadap penyisihan zat organik. Pada Gambar 10 menunjukkan fenomena $\mathrm{pH}$ air gambut setelah proses hibrid adsorpsi dan UF-PSf relatif tidak berubah terhadap tekanan operasi. Nilai $\mathrm{pH}$ permeat setelah melewati membran berkisar anatara 6,2-6,5 sesuai dengan hasil penelitian Aziza (2013) cenderung pH netral.

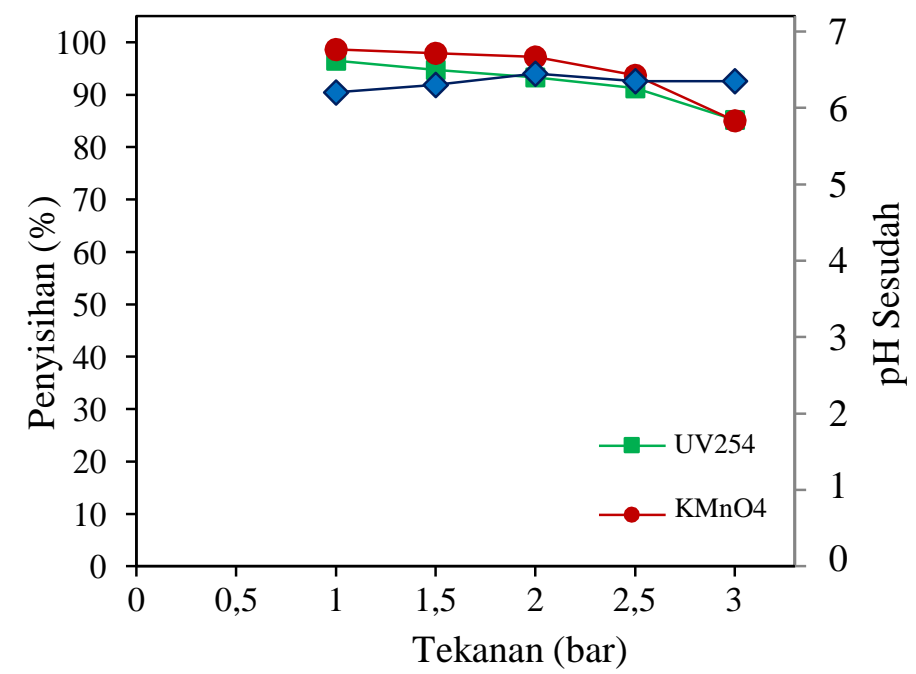

Gambar 10. Grafik hubungan antara Rejeksi BOA dan $\mathrm{pH}$ sesudah hibrid adsorpsi dan UF-PSf terhadap tekanan 


\subsubsection{Analisis Pemodelan Fouling Membran}

Pada penelitian ini dilakukan perhitungan MFI untuk mengetahui tingkat fouling yang paling kecil sampai yang paling besar pada masing-masing tekanan. Nilai MFI digunakan untuk memprediksi potensial fouling yang terjadi. MFI digambarkan sebagai gradien linear hubungan antara t/V terhadap V. Nilai MFI berbanding lurus terhadap pembentukan fouling. Semakin besar gradien MFI, maka potensi pembentukan fouling juga semakin besar, begitu pula sebaliknya.

Tekanan 1 bar memiliki nilai MFI paling besar yaitu 9.336.124,78 dibandingkan dengan nilai MFI pada tekanan 1,5 bar, 2 bar, 2,5 bar, dan 3 bar (Tabel 2). Hasil pemodelan MFI sesuai dengan hasil penelitian bahwa pada tekanan 1 bar potensial foulingnya paling tinggi mengingat rendahnya nilai fluks yang dihasilkan pada tekanan 1 bar. Berdasarkan kesesuaian model MFI dengan hasil penelitian, maka model MFI dapat dipakai untuk mengetahui potensial fouling yang terjadi pada proses hibrid adsorpsi dan UF-PSf penyisihan BOA air gambut.

Tabel 2. Nilai MFI pada masing-masing tekanan

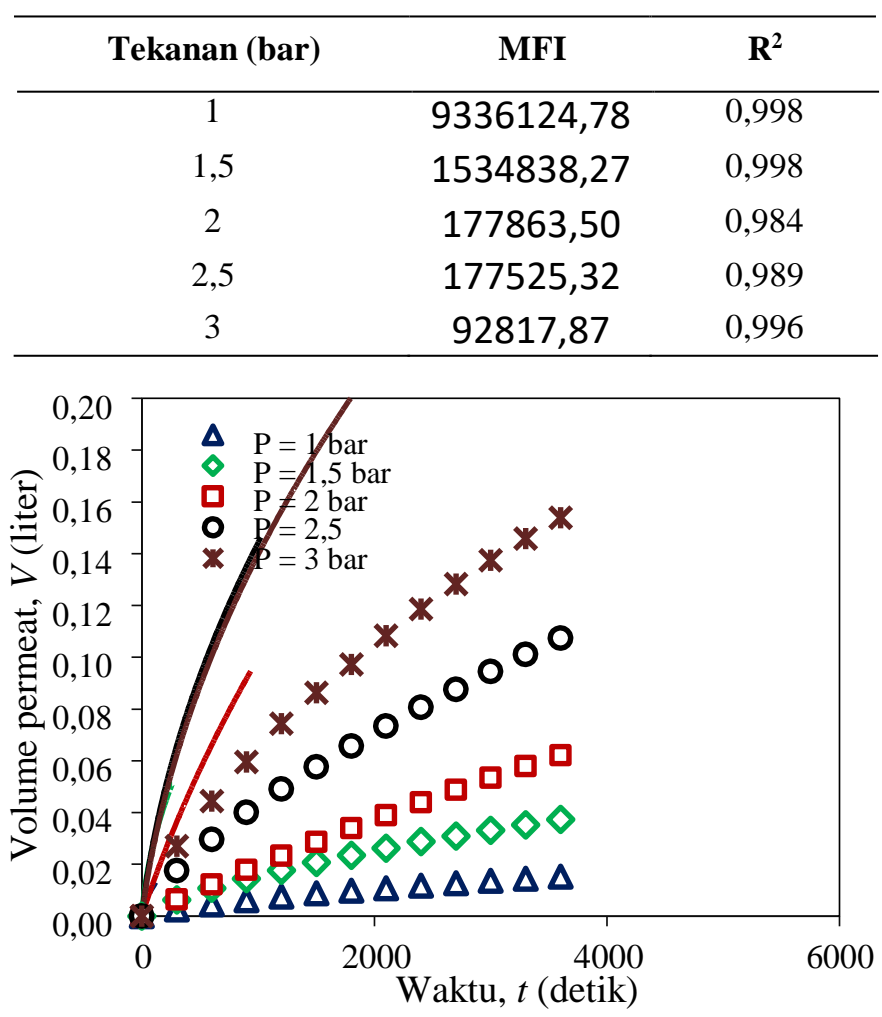

Gambar 11. Grafik MFI hubungan antara volume permeat terhadap waktu

Tabel 3. Nilai $S_{p b}$ pada masing-masing tekanan

\begin{tabular}{ccc} 
Tekanan (bar) & $\mathbf{S}_{\mathbf{p b}}$ & $\mathbf{R}^{\mathbf{2}}$ \\
\hline 1 & 34,985 & 0,989 \\
1,5 & 14,021 & 0,976 \\
2 & 3,005 & 0,977 \\
2,5 & 4,675 & 0,961 \\
3 & 3,477 & 0,972 \\
\hline
\end{tabular}


Pola model MFI menunjukkan hasil perbandingan lurus masing-masing tekanan operasi terhadap waktu. Kecenderungan yang terjadi adalah semakin landai kurva MFI, maka potensi terjadinya fouling semakin besar pula (Gambar 11). Jika kurva MFI tajam, maka potensi fouling yang terjadi relatif kecil terhadap waktu. Selain MFI, pemodelan pore blocking juga dapat digunakan. Nilai pore blocking berbanding lurus terhadap laju penyumbatan pada pori membran. Semakin besar gradien pore blocking, maka penyumbatan pori membran juga semakin cepat, begitu pula sebaliknya.

Tabel 3 menunjukkan tekanan 1 bar memiliki nilai $S_{\mathrm{pb}}$ yang paling besar yaitu 34,985 dibandingkan dengan nilai $S_{\mathrm{pb}}$ pada tekanan 1,5 bar, 2 bar, 2,5 bar, dan 3 bar. Berdasarkan perhitungan nilai $S_{\mathrm{pb}}$, diketahui penyumbatan pori tercepat pada membran terjadi pada tekanan 1 bar, dengan $\mathrm{R}^{2}$ tertinggi yaitu 0,989. Hasil pemodelan pore blocking juga dapat digunakan untuk memprediksi laju penyumbatan pori membran pada masing-masing tekanan. Pemodelan pore blocking digunakan untuk memprediksi laju penyumbatan pori pada membran pada jangka waktu yang panjang. Pola model pore blocking menunjukkan kenaikan seiring dengan lama waktu operasi (Gambar 12).

Berdasarkan Tabel 4 diketahui hasil pada model kurva saturated dengan variasi tekanan menunjukkan hasil yang kurang konsisten, yaitu pada tekanan 1 bar memiliki nilai $\mathrm{V}_{\text {max }}$ terendah, namun tidak sebanding dengan nilai $\mathrm{K}_{\mathrm{f}}$ yang memiliki nilai terendah pada tekanan 3 bar. Berdasarkan hasil tersebut, maka model kurva saturated kurang mempresentasikan tingkat jenuh pada tekanan yang bervariasi.

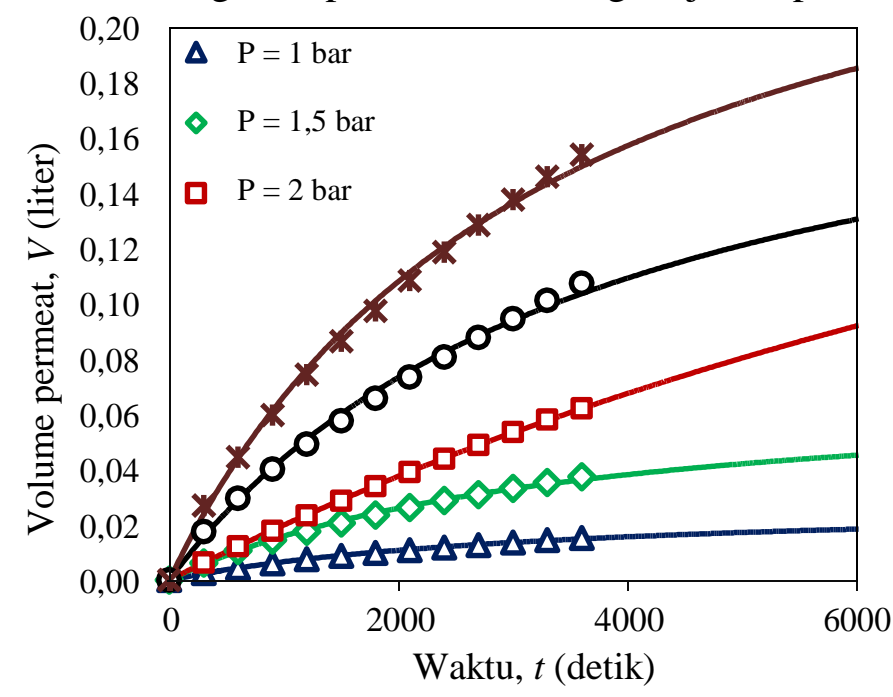

Gambar 12. Grafik Pore Blocking hubungan antara volume permeat terhadap waktu

Tabel 4. Nilai $\mathrm{V}_{\max }$ dan $\mathrm{K}_{\mathrm{f}}$ pada masing-masing tekanan

\begin{tabular}{ccc}
\cline { 3 - 3 } Tekanan (bar) & $\mathrm{V}_{\max }$ & $\mathrm{K}_{\mathrm{f}}$ \\
\hline 1 & 0,0247 & 44,20 \\
1,5 & 0,0576 & 41,97 \\
2 & 0,2609 & 200,22 \\
2,5 & 0,1631 & 42,68 \\
3 & 0,2245 & 37,72 \\
\hline
\end{tabular}




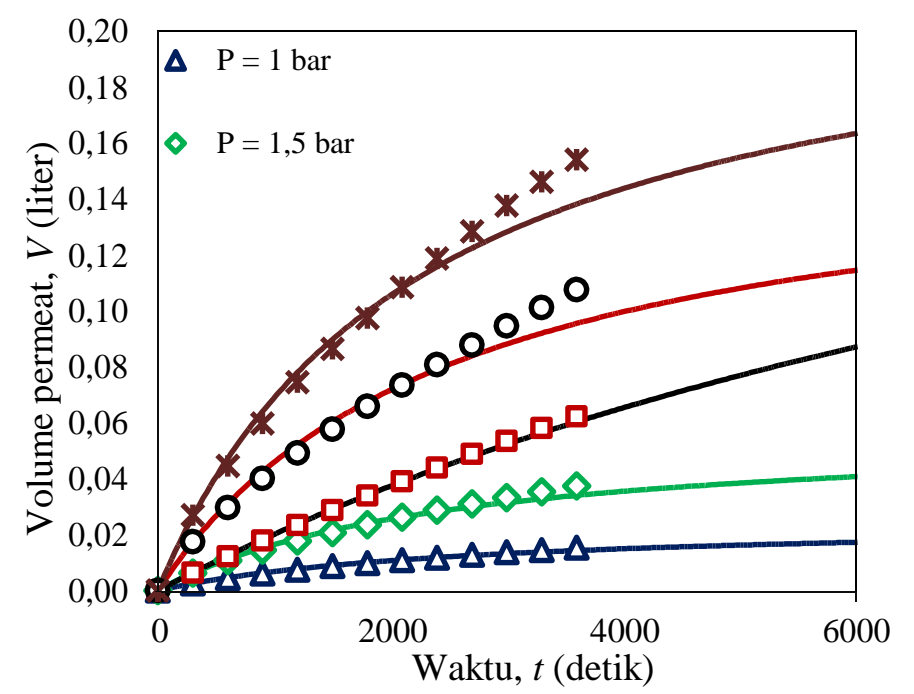

Gambar 13. Grafik kurva Saturated hubungan antara volume permeat terhadap waktu

Pemodelan kurva saturated digunakan untuk memprediksi tingkat kejenuhan membran dari cake layer yang terbentuk. Kejenuhan pada membran terjadi akibat menumpuknya BOA pada permukaan membran yang mengakibatkan penurunan fluks relatif kecil dibandingkan pada menit-menit awal operasi filtrasi membran UF-PSf. Model kurva saturated untuk variasi tekanan disajikan pada Gambar 13.

\section{KESIMPULAN}

Berdasarkan hasil analisis dan pembahsan mengenai pengaruh pra-perlakuan adsorpsi terhadap fouling membran UF-PSf pada penyisihan BOA air gambut dapat disimpulkan bahwa:

1. Pada kondisi optimum pH 4 dan dosis PAC $1040 \mathrm{mg} / \mathrm{L}$ dengan tekanan 1-3 bar diperoleh fluks tertinggi pada tekanan 3 bar sebesar 85,064 L/m2.jam dengan rejeksi sebesar 85,24\% (UV 254$)$ dan $85,07 \%\left(\mathrm{KMnO}_{4}\right)$ merupakan kondisi tekanan operasi terbaik proses hibrid adsorpsi dan UF-PSf.

2. MFI merupakan pemodelan yang tepat untuk menggambarkan potensial fouling pada proses hibrid adsorpsi dan UF-PSf pada penyisihan BOA air gambut.

\section{Daftar Rujukan}

Aisyahwalsiah, A. (2013). Optimasi Pengolahan Air Gambut Menggunakan Proses Gabungan Koagulasi dengan Tanah Lempung Gambut (TLG) dan Adsorpsi Karbon Aktif. Skripsi/Tugas Akhir S-1 Program Studi Teknik Lingkungan. Universitas Lambung Mangkurat. Banjarbaru

Arhin, S. G., Banadda, N., Komakech, A. J., Kabenge, I. dan Wanyama, J. (2016). Membrane Fouling Control in Low Pressure Membranes: A Review on Pretretament Techniques for Fouling Abatement. Environ. ENg. Res. 21. 109-120

Aziza, S. (2013). Proses Hybrid Adsorpsi dan Ultrafiltrasi pada Penyisihan Bahan Organik Alami (BOA) dalam Air Gambut: Pengaruh Jenis Adsrben Terhadap Fouling Membran Skripsi/Tugas Akhir S-1 Program Studi Teknik Lingkungan. Universitas Lambung Mangkurat. Banjarbaru

Campinas, M. dan Rosa, M. J. (2010). Assessing PAC Contribution to the NOM Fouling Control in PAC/UF Systems. Water Research. Vol. 44. 16636-1644

Edzwald, J. K. dan Tobiason, J. E. (1999). Enhanced Coagulation: Us Requirements and a Broader View. Water Science \& Technology. Vol. 40. 63-70

Gao, W. H., Liang, J. M., Han, M., Chen, Z. I., Han, Z. S. dan Li, G. B. (2011). Membrane Fouling Control in Ultrafiltration Technology for Drinking Water Production: A review. Desalination. 5 . 
Herwati, N., Mahmud dan Abdi, C. (2015). Pengaruh pH Air Gambut Terhadap Fouling Membran Ultrafiltrasi. Jukung Jurnal Teknik Lingkungan. 1. 59-73

Kim, J., Cai, Z. dan Benjamin, M. M. (2008). Effects of Adsorbents on Membran Fouling by Natural Organic Matter. Journal of Membrane Science. 310. 356-364

Konieczny, K. dan Klomfas, G. (2002). Using Activated Carbon to Improve Natural Water Treatment by Porous Membranes. Desalination. 147. 109-116

Kurniawan, C., Waluyo, T. B. dan Sebayang, P. (2011). Analisis Ukuran Partikel Menggunakan Free Software Image-J. Seminar Nasional Fisika. Pusat Penelitian Fisika-LIPI.

Lee, C., Bae, S., Han, S. dan Kang, L. (2007). Application of Ultrafiltration Hybrid Membrane Process for Reuse of Secondary Effluent. Desalination. 202. 239-246

Mahmud dan Noor, R. (2005). Kinetika Fouling Membran Ultrafiltrasi (UF) Pada Pengolahan Air Berwarna: Pengaruh Interval dan Lamanya Pencucian Balik (Backwashing) Membran. InfoTeknik. Vol. 6. (62-69)

Malczewska, B. dan Benjamin, M. M. (2016). Efficacy og Hybrid Adsorption/Membrane Pretreatment for Low Pressure Membrane. Water Research. 99. 263-271

Mozia, S., Tomaszewska, M. dan Morawski, A. W. (2005). Studies on the Effect of Humic Acids and Phenol on Adsorption-Ultrafiltration process performance. Water Research. Vol. 39. 501- 509

Mulder, M. (1996). Basic Principles of Membrane Technology. Kluwer Academic Publishers. London

Nilson, A. dan DiGiano, F. A. (1996). Influence of NOM Composition on Nanofiltration. J. AWWA. Vo. 88. 53-66

Notodarmojo, S. dan Deniva, A. (2004). Penurunan Zat Organik dan Kekeruhan Menggunakan Teknologi Membran Ultrafiltrasi dengan Sistem Aliran Dead-End (Studi Kasus: Waduk Saguling, Padalarang). PROC. ITB Sains \& Tek. Vol. 36 A. 63-82

Pratiwi, N. E., Husaini dan Suhartono, E. (2016). Filtrasi Campuran Pasir dan Ampas Tahu Kering Sebagai Adsorben Logam Besi dan Mangan pada Air Gambut. Jurnal Berkala Kesehaan. Vol. 2. 88-97

Riduan, R. (2005). Studi Pengaruh Penambahan Karbon Aktif pada Optimasi Penurunan Warna dan Kandungan Organik Pada Air Gambut Menggunakan Membran Ultrafiltrasi. Info Teknik. Vol. 6. 54-60

Saputera, A. A. (2014). Proses Hibrid Koagulasi-Ultrafiltrasi dalam Penyisihan Bahan Organik Alami (BOA) pada Air Gambut: Pengaruh Variasi Dosis Koagulasi terhadap Fouling Membran. Skripsi/Tugas Akhir S-1 Program Studi Teknik Lingkungan. Universitas Lambung Mangkurat. Banjarbaru

Saputri, G. M. I. (2008). Penurunan Warna Air Gambut dengan Adsorpsi Lempung Tanah Gambut dan Membran Selulosa Asetat. Skripsi/Tugas Akhir S-1 Fakultas Matematika dan Ilmu Pengetahuan Alam. Universitas Lambung Mangkurat. Banjarbaru

Sivakumar, M., Mohan, D. R. dan Rangarajan, R. (2006). Studies on Cellulose Acetate-Polysulfine Ultrafiltration Membranes II. Effect of Additive Concentration. Journal of Membane Science. 268. 208-219

Syarfi, H. S. (2007). Rejeksi Zat Organik Air Gambut dengan Membran Ultrafiltrasi. Jurnal Sains dan Teknologi. Vol. 6.

Tang, C., He, Z., Zhao, F., Liang, X. dan Li, Z. (2014). Effects of cations on the formation of ultrafiltrasi membrane fouling layers when filtering fulvic acid. Desalination. 352. 174- 180

Tutriyanti. (2017). Sintesis dan Karakterisasi Membran Polisulfon dengan Teknik Inversi Fasa: Pengaruh Konsentrasi Impregnan $\mathrm{KCl}$ pada Koagulan terhadap Struktur Pori Membran. Skripsi/Tugas Akhir S-1 FMIPA. Universitas Lambung Mangkurat. Banjarbaru

Wardani, A. K. (2013). Pengaruh Aditif pada Pembuatan Membran Ultrafiltrasi Berbasis Polisulfon untuk Pemurnian Air Gambut. Institut Teknologi Bandung. Bandung

Wenten, I. G. (1999). Teknologi Membran Industrial. Institut Teknologi Bandung. Bandung

Widjaja, T., Altway, A. dan Soeprijanto. (2009). Studi Proses Hybrid: Adsorpsi pada Karbon Aktif/Membran Bioreaktor untuk Pengolahan Limbah Cair Industri. Seminar Nasional Teknik Kimia Indonesia. TPL05-1. 
Yunos, M. Z., Harun, Z., Basri, H. dan Ismail, A. F. (2014). Studies on Fouling by Natural Organic Matter (NOM) on Polysulfone Membranes: Effect of Polyethylene Glycol (PEG). Desalination. 333. 36-44

Zularisam, A., Ismail, A., Salim, M., Sakinah, M. dan Ozaki, H. (2007). The Effect of Natural Organic Matter (NOM) Fractions on Fouling Characteristics and Flux Recovery of Ultrafiltration Membranes. Desalination. Vol. 212. 191-208

Zularisam, A. W., Ismail, A. F., Salim, M. R., Sakinah, M. dan Matsuura, T. (2009). Application of coagulation-ultrafiltration hybrid process for drinking water treatment: Optimization of operating conditions using experimental design. Separation and Purification Technology. 65. 193-210

Zularisam, A. W., Ismail, A. F. dan Salim, R. (2006). Behaviours of Natural Organic Matter in 231 Membrane Filtration for Surface Water Treatment-A Review. Desalination. Vol. 194. 211- 
JTAM Teknik Lingkungan Universitas Lambung Mangkurat, Vol 1 (2) Tahun 2018

$\underline{\text { Halaman ini senagaja di kosongkan }}$ 